\title{
Impact of iron limitation on primary production (dissolved and particulate) and secondary production in cultured Trichodesmium sp.
}

\author{
Emma J. Rochelle-Newall ${ }^{1, *}$, Céline Ridame ${ }^{2}$, Céline Dimier-Hugueney ${ }^{2,3}$, \\ Stéphane L'Helguen ${ }^{4}$
}

${ }^{1}$ IRD, iEES-Paris, UMR7618 - uPMC - CNRS - INRA - Paris 7 - UPEC, 46 rue d'Ulm, 75005, Paris, France
${ }^{2}$ UPMC, Univ. Paris 06, UMR7159 LOCEAN, 4 Place Jussieu, 75005, Paris, France
39MC, Univ. Paris 06, Station Biologique de Roscoff, UMR 7144, Place Georges Teissier - Roscoff, France
${ }^{3}$ UPMC,

${ }^{4}$ LEMAR, Laboratoire des Sciences de l'Environnement Marin, UMR UBO/CNRS/IRD 6539, IUEM, 29280 Plouzané, France

\begin{abstract}
Diazotrophic cyanobacteria play an important role in biogeochemical cycles of carbon and nitrogen and, hence, in oceanic productivity in the tropical and subtropical regions of the ocean. Although many studies have examined the impact of iron $(\mathrm{Fe})$ limitation on particulate primary production and dinitrogen $\left(\mathrm{N}_{2}\right)$ fixation in the colonial cyanobacterium Trichodesmium, none have looked at the impact of Fe limitation on the percentage extracellular release (PER) and secondary production (SP) in Fe-limited cultures of this cyanobacterium. Here, we present the results of a series of culture experiments during which we examined the impact of 3 concentrations of dissolved iron (DFe) on total primary production (TPP = dissolved + particulate primary production, i.e. DPP + PPP), PER and on SP. Under severe Fe limitation (5 nM DFe), biomass, growth rates, TPP and $\mathrm{N}_{2}$ fixation were strongly reduced, while PER increased relative to the rates observed at the highest Fe concentration. Moreover, reducing Fe concentration induced an increase in the percentage of photosynthetically fixed $\mathrm{C}$ used for algal growth, while the percentage of $\mathrm{C}$ used to support algal respiration decreased. Reduced Fe concentrations also induced a decrease in SP and in the SP:DPP ratio, indicating that the efficiency of transfer of fixed carbon from autotrophic to heterotrophic processes is reduced. This suggests that $\mathrm{Fe}$, either directly through influencing cellular processes or indirectly through influencing organic matter structure or nitrogen availability, is controlling SP and, thus, microbial carbon utilization. These results suggest that the amount of carbon entering into the microbial loop may be reduced under Fe limitation, thus leading to an accumulation of dissolved organic carbon with potentially important impacts on microbial carbon cycling and, ultimately, on the biological carbon pump.
\end{abstract}

KEY WORDS: Fe limitation - Diazotrophic cyanobacteria $\cdot$ Carbon cycling $\cdot$ Dissolved primary production $\cdot$ Secondary production $\cdot$ Bioavailability $\cdot$ DOC $\cdot$ PER

Resale or republication not permitted without written consent of the publisher

\section{INTRODUCTION}

In tropical and subtropical nutrient-poor ocean waters, the diazotrophic filamentous cyanobacteria Trichodesmium spp. form extensive blooms and can dominate phytoplankton assemblages. Moreover, Trichodesmium activity can be responsible for a major proportion of organic matter production and carbon export in the ocean (Capone 2001, Michaels et al. 2001). As a consequence, several investigations have focused on the biogeochemical factors, such as ambient iron (Fe) and/or phosphorus concentrations, controlling the growth and activity of Trichodesmium and other dinitrogen $\left(\mathrm{N}_{2}\right)$-fixing microorganisms (Mills et al. 2004, Berman-Frank et al. 2007a, Ridame et al. 2011, Jacq et al. 2014). 
Dinitrogen fixation or diazotrophy is the biological process by which dissolved $\mathrm{N}_{2}$ is reduced to ammonium. This reaction is catalyzed by 2 different nitrogenase enzymes: dinitrogenase and dinitrogenase reductase, both of which contain Fe. Furthermore, the high energetic cost (ATP, adenosine triphosphate) of $\mathrm{N}_{2}$ fixation imposes an additional Fe requirement for increased photosynthetic capacity (Kustka et al. 2003a). As a consequence, diazotrophic cyanobacteria have relatively high Fe requirements and it is estimated that $\mathrm{N}_{2}$-fixing organisms such as Trichodesmium require up to 5 times more Fe than non-diazotrophic phytoplankton (Berman-Frank et al. 2001, Kustka et al. 2003b). In both cultured and natural populations, reduced $\mathrm{N}_{2}$ fixation has been observed in Trichodesmium at low dissolved Fe concentrations (Berman-Frank et al. 2001, Moore et al. 2009). This is probably due to a decrease in the amount of nitrogenase produced under Fe limitation (Küpper et al. 2008). Thus, in regions of low Fe availability, $\mathrm{N}_{2}$ fixation can be limited by Fe or co-limited by Fe and phosphorus (Mills et al. 2004), particularly in large open ocean areas, isolated from continental inputs and weakly impacted by the atmospheric deposition of desert dust.

Carbon and $\mathrm{N}_{2}$ fixation are integrally linked as the photosynthetic production of NADPH and ATP are required for both fixation of $\mathrm{CO}_{2}$ and $\mathrm{N}_{2}$. Fe is necessary for the photosynthetic apparatus with large amounts of Fe being required for the photosynthetic electron transport chain of Trichodesmium spp. (Kustka et al. 2003b). Thus, low Fe concentrations limit not only primary production and the production of biomass through a direct control on $\mathrm{CO}_{2}$ fixation but also through its control of fixed nitrogen availability.

During photosynthesis, autotrophic phytoplankton, including cyanobacteria, produce and release a range of dissolved organic carbon (DOC) compounds into the water column (Marañón et al. 2004). This freshly produced DOC is the principal autochthonous form of DOC in aquatic ecosystems and 3 previous reviews have provided comprehensive summaries that highlight the importance of DOC released during photosynthesis to microbial carbon cycling (Nagata 2000, Carlson 2002, Bertilsson \& Jones 2003). Several other studies have pointed towards the role of certain factors such as nutrient limitation, growth stage, light and UV radiation levels or contaminants in controlling the production of DOC during photosynthesis (e.g. Norrman et al. 1995, Conan et al. 2008, Rochelle-Newall et al. 2008b). However, to our knowledge, none have examined the impact of Fe limitation on the production of DOC during photosynthesis in the colonial cyanobacterium Trichodesmium.

As the production of DOC during photosynthesis represents the principal carbon source for heterotrophic secondary production (SP), there should be a tight relationship between the production of organic matter by autotrophic processes and the removal of organic matter by heterotrophic processes. This is true in cultures where external sources of organic matter are excluded, as well as in sites isolated from terrestrial inputs such as the open ocean. Moreover, it is a widely accepted idea that newly produced dissolved primary production (DPP) should be labile to bacteria. However, this hypothesis still remains to be tested under a variety of conditions, such as micronutrient limitation. This is particularly important when cyanobacteria are considered, as the work of Renaud et al. (2005) and of Nausch (1996) on Trichodesmium spp. suggested that shifts in the quality of DOC and, hence, its bioavailability to heterotrophs occurs during growth. However, none of these authors examined the impact of micro-nutrient limitation on the bioavailability of this freshly produced DOC.

Here, we present the results of a culture based investigation to assess the impact of Fe limitation (1) on the percentage of extracellular release (PER) of fixed carbon in the diazotrophic cyanobacterium Trichodesmium erythraeum, (2) on SP and (3) on microbial utilization of DPP.

\section{MATERIALS AND METHODS}

Triplicate cultures (2 1) of the diazotrophic cyanobacterium Trichodesmium erythraeum IMS 101 were grown at 3 dissolved Fe concentrations: 5, 13 and 100 nM Fe. Samples were collected during a $13 \mathrm{~d}$ incubation for measurement of particulate organic carbon (POC), $\mathrm{N}_{2}$ fixation, particulate primary production (PPP), DPP and SP. At each time point ( 7 total), between 100 and $200 \mathrm{ml}$ were sampled, depending on the measurements conducted.

\section{Culture conditions}

Before use, all bottles and materials were cleaned with diluted $\mathrm{HCl}$ (Suprapur quality) and rinsed with ultra-pure water (>18.2 M $\Omega$ ). All manipulations were conducted in a clean laboratory in a sterile laminar flow hood (class 100) using sterile and 
trace-metal clean techniques. Batch cultures of $T$. erythraeum IMS 101 were grown in polycarbonate bottles under artificial light (Fluorescence tubes, type MLR350T, Sanyo, $150 \mu \mathrm{mol}$ photon $\mathrm{m}^{-2} \mathrm{~s}^{-1}, 12 \mathrm{~h}$ : $12 \mathrm{~h}$ light:dark cycle) at $27^{\circ} \mathrm{C}$. Non-axenic cultures were gently mixed using orbital shakers to prevent cell sedimentation. Trichodesmium was grown in sterile medium with no added fixed nitrogen that was prepared with Suprapur quality salts and reagents (modified YBCII medium, after Chen et al. 1996). The medium was sterilized by autoclaving and by $0.2 \mu \mathrm{m}$ filtration. $\mathrm{pH}$ was adjusted to 8.1 with Suprapur $\mathrm{NaOH}$ before autoclaving. After autoclaving, the medium was enriched with sterile $(0.2 \mu \mathrm{m}$ filtration) phosphate $(50 \mu \mathrm{M})$, vitamins $\left(\mathrm{B}_{12}\right.$, biotin, thiamine $\mathrm{HCl}$ ), $\mathrm{NaHCO}_{3}$ and trace metals (Co, $\mathrm{Mo}, \mathrm{Cu}$, $\mathrm{Zn}, \mathrm{Mn})$. After $24 \mathrm{~h}$ equilibrium, the $\mathrm{pH}$ was measured and readjusted to 8.1. Finally, $\mathrm{Fe}\left(\mathrm{FeCl}_{3}\right)$ was added to give the desired concentrations $(5,13$ and $100 \mathrm{nM}$, including a background concentration in the medium of $3 \mathrm{nM}$, see Table 1) complexed with $2 \mu \mathrm{M}$ of EDTA, a metal ion buffering agent. Trichodesmium was grown in each Fe treatment for a minimum of 10 generations before the experiment to fully acclimate cells to their respective Fe treatments. In the media, dissolved Fe (DFe) was noted as Fe-EDTA chelates and inorganic dissolved $\mathrm{Fe}$ noted as Fe'. EDTA acts as a Fe' buffer in artificial seawater and insures that the $\mathrm{Fe}^{\prime}$ concentration remains constant during the exponential growth phase of cells in batch cultures. Fe' represents the concentration of biologically available dissolved inorganic $\mathrm{Fe}$ hydrolysis species $\left(\mathrm{Fe}[\mathrm{OH}]_{2}, \mathrm{Fe}[\mathrm{OH}]_{3}\right.$ and $\left.\mathrm{Fe}[\mathrm{OH}]_{4}^{-}\right) . \mathrm{Fe}^{3+}$ is also bioavailable for microorganisms but as it is approximately 10 orders of magnitude lower than $\mathrm{Fe}^{\prime}$ at $\mathrm{pH} 8.1$ (Hudson et al. 1992), it can be ignored in this work. Fe' concentrations were computed from the Fe complexation data in Sunda \& Huntsman (2003). In the cultures containing 5, 13 and $100 \mathrm{nM} \mathrm{DFe,} \mathrm{the} \mathrm{computed} \mathrm{Fe'} \mathrm{con-}$ centrations were $0.26,0.69$ and $5.2 \mathrm{nM}$. The latter value is invalid, as it exceeds the solubility limit for $\mathrm{Fe}$ with respect to ferric hydroxide precipitation ( 1.4 nM in Sunda \& Huntsman 2003). However, it should be noted that recent studies have shown that Fe hydroxides and oxides can be utilized by Trichodesmium after active dissolution through cell-surface processes (Rubin et al. 2011). The variation of $\mathrm{pH}$ between the beginning and the end of the exponential growth phase (6 d duration) for all treatments was about $0.1 \mathrm{pH}$ unit (8.1 to 8.2) which avoided $\mathrm{CO}_{2}$ limitation and limited $\mathrm{pH}$ effects on Fe chelation by EDTA (Sunda \& Huntsman 2003).

\section{Primary and secondary production}

PPP and DPP were measured using $\mathrm{NaH}^{14} \mathrm{CO}_{3}$ following the methods described in Rochelle-Newall et al. (2008b). The only differences were that $39 \mathrm{ml}$ culture samples were inoculated with 0.37 (Days 3 and 6), 0.425 (Days 9 and 11) and 0.74 (Day 13) $\mathrm{MBq}$ of $\mathrm{NaH}^{14} \mathrm{CO}_{3}$ (Perkin-Elmer). The samples were incubated under the same light intensity as the cultures for $4 \mathrm{~h}$, centered around local noon. At the end of the incubation, samples were carefully filtered at low vacuum pressure onto $0.4 \mu \mathrm{m}$ polycarbonate filters (Whatman Cyclopore). After acidification and drying of the filters $\left(24 \mathrm{~h}\right.$ at $\left.45^{\circ} \mathrm{C}\right), 5 \mathrm{ml}$ of scintillation cocktail (Ultima Gold, Packard Instruments) was added. The amount of ${ }^{14} \mathrm{C}$ incorporated into the particulate phase was calculated using an inorganic carbon concentration of $25700 \mu \mathrm{g} \mathrm{C}^{-1}$ (Marañón et al. 2004). DPP was measured in the filtrate after acidification and agitation ( $24 \mathrm{~h}$ ) followed by addition of $15 \mathrm{ml}$ of scintillation cocktail (Ultima Gold XR, Packard Instruments). All DPP measurements exceeded the blank by a factor of at least 3. PER is calculated by dividing DPP by total primary production $(\mathrm{TPP}) \times 100$, where TPP is the sum of PPP and DPP. In order to take into account the differences in biomass between treatment, TPP, DPP and SP were normalized to POC concentration $\left(\mathrm{TPP}^{\mathrm{POC}}, \mathrm{DPP}^{\mathrm{POC}}\right.$ and $\mathrm{SP}^{\mathrm{POC}}$, respectively) and values are reported as ng $\mathrm{C} \mu \mathrm{g} \mathrm{POC}^{-1} \mathrm{~h}^{-1}$.

$\mathrm{SP}$ was measured using ${ }^{3} \mathrm{H}$-leucine, following the method of Smith \& Azam (1992) as detailed in Rochelle-Newall et al. (2008a). Triplicate $1.4 \mathrm{ml}$ subsamples along with a trichloroacetic acid (TCA)killed control (72 $\mu$ l 100\% TCA) were incubated in the dark for $1 \mathrm{~h}$ in the presence of $40 \mathrm{nM}$ (Days 3 to 11) or $80 \mathrm{nM}$ (Day 13; final concentration) high specific activity ${ }^{3} \mathrm{H}$-leucine (Perkin Elmer) at the incubation temperature. The incorporation of ${ }^{3} \mathrm{H}$-leucine into the particulate fraction was counted after addition of $0.5 \mathrm{ml}$ of scintillation cocktail (Ultima Gold MV, Perkin Elmer). Leucine uptake was converted to carbon using the conversion factor $1.55 \mathrm{~kg} \mathrm{C} \mathrm{mol}^{-1}$ leucine (Kirchman 2001). Several authors have recently shown that phytoplankton (including cyanobacteria) can take up ${ }^{3} \mathrm{H}$-labelled leucine during incubations (Kamjunke \& Tittel 2008, Mulholland et al. 2011), although this remains to be shown in diazotrophic cyanobacteria such as Trichodesmium. Therefore, in this work, we considered SP to be the uptake of ${ }^{3} \mathrm{H}$-labelled leucine by heterotrophic processes of both bacteria and cyanobacteria because we cannot rule out the uptake of leucine by Trichodesmium. 


\section{$\mathrm{N}_{2}$-fixation rate and particulate organic carbon and nitrogen}

Culture incubations for measurements of $\mathrm{N}_{2}$-fixation rate were performed using the ${ }^{15} \mathrm{~N}_{2}$-tracer addition method. Briefly, ${ }^{15} \mathrm{~N}_{2}$ gas (98\%, EURISOTOP) was added to a subsample of culture (from 45 to $75 \mathrm{ml}$ ) in polycarbonate bottles equipped with septum caps using a gas-tight syringe. ${ }^{15} \mathrm{~N}_{2}$ tracer was added to obtain a final enrichment of the $\mathrm{N}_{2}$ pool of about 10 atom $\%$ excess. After an incubation of about $4 \mathrm{~h}$, the samples were filtered onto pre-combusted $25 \mathrm{~mm}$ $\mathrm{GF} / \mathrm{F}$ filters and stored at $-20^{\circ} \mathrm{C}$. Sample filters were dried for $48 \mathrm{~h}$ at $40^{\circ} \mathrm{C}$ before analysis. Organic nitrogen (PON) and POC concentration in the particulate matter as well as ${ }^{15} \mathrm{~N}$-enrichment were quantified with a mass spectrometer (Delta plus, ThermoFisher Scientific) coupled with a C/N analyser (Flash EA, ThermoFisher Scientific) via a type III-interface. Standard deviations (SD) were $0.004 \mu \mathrm{mol} \mathrm{l}^{-1}$ and $0.009 \mu \mathrm{mol} \mathrm{l}^{-1}$ for PON and POC, respectively, and 0.0001 atom $\%$ for ${ }^{15} \mathrm{~N}$ enrichment. $\mathrm{N}_{2}$-fixation rates were calculated by isotope mass balance as described by Montoya et al. (1996). Specific growth rates $(\mu)$ were determined during the exponential phase of growth (Day 0 to Day 6) from linear regression of the natural logarithm of POC concentrations versus time.

\section{Statistical analyses}

Significant differences between treatments were tested using the Xlstat 2012 (Addinsoft) software. Analysis of variance (ANOVA) with time and treatment as fixed factors was used to test the significance of the differences between treatments after checking that the assumptions of the ANOVA were met. When necessary, the data were log-transformed to assure normality. When a significant difference was observed, an a posteriori test (Fisher's least significant difference [LSD]) was used.

\section{RESULTS}

\section{Biomass, growth rate and $\mathrm{N}_{2}$ fixation}

The carbon-based specific growth rate $(\mu)$, measured as the POC biomass, increased with increasing Fe concentration (Table 1, Fig. 1). The exponential growth phase, characterised by maximum and balanced growth rates $(\mu)$, occurred from Day 0 to Day 6 in all 3 Fe cultures. After Day 6, the specific growth rates were slower. At the end of the incubation, the highest POC concentration was observed in the $100 \mathrm{nM}$ DFe treatment $(8818 \pm 586$ [mean $\pm \mathrm{SE}] \mu g \mathrm{l}^{-1}$, a 20 -fold increase from time zero, $\mathrm{T} 0$ ) and the lowest POC concentration was observed in the lowest DFe treatment (3779 $\pm 151 \mu \mathrm{g} \mathrm{l}^{-1}$, a 4 -fold increase from T0).

The carbon-based specific growth rates calculated during the exponential phase (from Day 0 to 6 ) were

Table 1. Growth rate $\left(\mu, \mathrm{d}^{-1}\right), \mathrm{N}_{2}$-fixation rate $\left(\mathrm{N}_{2}\right.$ fix, $\mathrm{ng} \mathrm{N} \mu \mathrm{g}$ POC [particulate organic carbon] ${ }^{-1} \mathrm{~h}^{-1}$ ), total primary production (TPP ${ }^{\mathrm{POC}}$, ng C $\mu \mathrm{g} \mathrm{POC}^{-1} \mathrm{~h}^{-1}$ ), dissolved primary production (DPP ${ }^{\mathrm{POC}}$, ng $\mathrm{C} \mu \mathrm{POC}^{-1} \mathrm{~h}^{-1}$ ), cellular C: $\mathrm{N}$ ratio (mol $\mathrm{mol}^{-1}$ ), PER $(\%)$, secondary production ( $\mathrm{SP}^{\mathrm{POC}}, \mathrm{ng} \mathrm{C} \mu \mathrm{g}$ $\left.\mathrm{POC}^{-1} \mathrm{~h}^{-1}\right)$, SP:TPP and SP:DPP ratios during the exponential phase (Day 0 to 6 ) of Trichodesmium cultures grown under different dissolved iron (DFe) and inorganic dissolved iron (Fe') concentrations. The computed Fe' concentration corresponding to DFe of $100 \mathrm{nM}$ exceeds the solubility limit for $\mathrm{Fe}$ with respect to ferric hydroxide precipitation. Means $\pm \mathrm{SE}$ are shown. Different letters in brackets correspond to statistically different means $(\mathrm{p}<0.05)$

\begin{tabular}{|lccc}
\hline \multirow{2}{*}{ Variable } & \multicolumn{3}{c}{ DFe (Fe') concentration $(\mathrm{nM})$} \\
\cline { 2 - 4 } & $5(0.26)$ & $13(0.69)$ & $100(-)$ \\
\hline$\mu$ & $0.15 \pm 0.04(\mathrm{~A})$ & $0.23 \pm 0.00(\mathrm{~B})$ & $0.34 \pm 0.03(\mathrm{C})$ \\
$\mathrm{N}_{2}$ fix. & $0.40 \pm 0.10(\mathrm{~A})$ & $0.70 \pm 0.20(\mathrm{~B})$ & $1.96 \pm 0.28(\mathrm{C})$ \\
$\mathrm{TPP}^{\mathrm{POC}}$ & $29.4 \pm 8.5(\mathrm{~A})$ & $31.6 \pm 10.9(\mathrm{~A})$ & $97.0 \pm 27.8(\mathrm{~B})$ \\
$\mathrm{DPP}$ & $2.85 \pm 0.6(\mathrm{~A})$ & $2.27 \pm 1.5(\mathrm{~A})$ & $2.29 \pm 1.1(\mathrm{~A})$ \\
$\mathrm{C}: \mathrm{N}$ & $8.0 \pm 0.6(\mathrm{~A})$ & $6.6 \pm 0.2(\mathrm{~B})$ & $5.4 \pm 0.2(\mathrm{C})$ \\
$\mathrm{PER}$ & $10.6 \pm 4.8(\mathrm{~A})$ & $8.6 \pm 4.3(\mathrm{~A})$ & $2.5 \pm 1.1(\mathrm{~B})$ \\
SP & & \\
SP:TPP & $0.83 \pm 0.31(\mathrm{~A})$ & $1.00 \pm 0.2(\mathrm{~B})$ & $1.8 \pm 0.2(\mathrm{C})$ \\
SP:DPP & $0.03 \pm 0.02(\mathrm{~A})$ & $0.04 \pm 0.01(\mathrm{~A})$ & $0.02 \pm 0.00(\mathrm{~A})$ \\
& $0.30 \pm 0.10(\mathrm{~A})$ & $0.50 \pm 0.20(\mathrm{~A})$ & $0.85 \pm 0.35(\mathrm{~B})$ \\
\end{tabular}

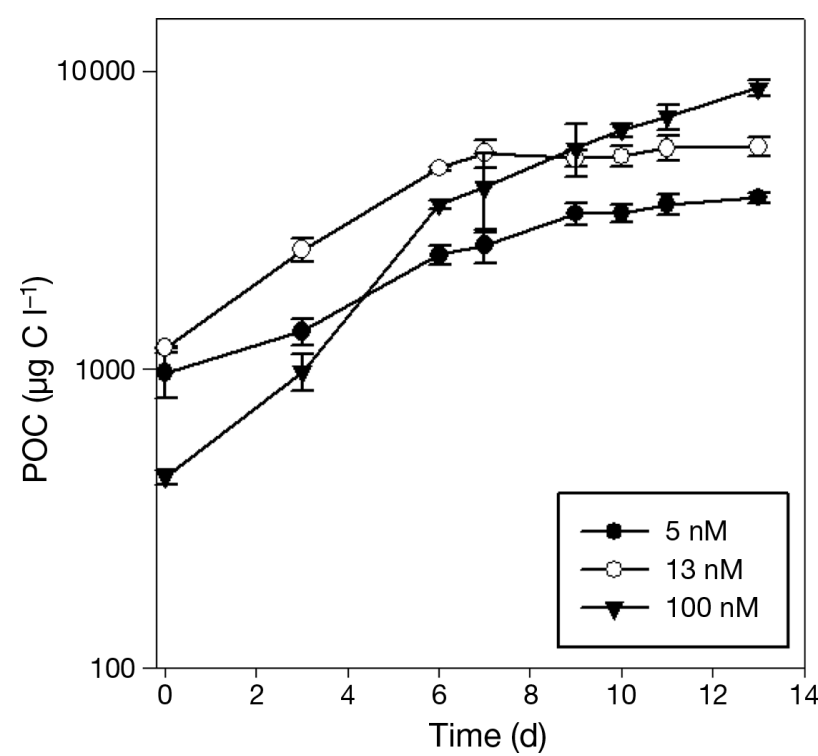

Fig. 1. Particulate organic carbon (POC) concentration $\left(\mu g \mathrm{l}^{-1}\right)$ in log scale versus time (d) in the 3 different dissolved iron treatments. Error bars are SE 
significantly different between all the Fe treatments $\left(p<0.05\right.$, Table 1) and declined from $0.34 \pm 0.03 \mathrm{~d}^{-1}$ to $0.15 \pm 0.04 \mathrm{~d}^{-1}$ as DFe was reduced from $100 \mathrm{nM}$ to $5 \mathrm{nM}$ (Table 1).

During the exponential phase (Days 0 to 6 ), $\mathrm{N}_{2}$-fixation rate was controlled by the Fe concentration as shown by significantly different rates between all Fe treatments (Table 1). These rates decreased from $1.96 \pm 0.28 \mathrm{ng} \mathrm{N} \mu \mathrm{POC}^{-1} \mathrm{~h}^{-1}$ to $0.40 \pm 0.10 \mathrm{ng} \mathrm{N} \mu \mathrm{g}$ $\mathrm{POC}^{-1} \mathrm{~h}^{-1}$ for DFe concentrations of $100 \mathrm{nM}$ and $5 \mathrm{nM}$, respectively $(\mathrm{p}<0.05)$. The molar $\mathrm{C}: \mathrm{N}$ ratio increased significantly during the exponential phase (Day 0 to Day 6) from $5.4 \pm 0.2$ to $8.0 \pm 0.6$ with increasing Fe stress $(\mathrm{p}<0.05$, Table 1$)$.

\section{Primary and secondary production}

$\mathrm{TPP}^{\mathrm{POC}}$ varied during the incubation and with $\mathrm{DFe}$ concentration (Fig 2A, Table 1). Overall, the rates of $\mathrm{TPP}^{\mathrm{POC}}$ were significantly higher in the highest $\mathrm{Fe}$ treatment than in the 2 lower Fe treatments $(\mathrm{p}<0.05)$.
The lowest $\mathrm{TPP}^{\mathrm{POC}}$ were observed at the end of the experiment for all Fe treatments (Day 13). In the exponential phase (Day 0 to Day 6), TPP ${ }^{\mathrm{POC}}$ of Trichodesmium was highly dependent on Fe concentration as shown by the significant decrease (factor of 3.3) from $97.0 \mathrm{ng} \mathrm{C} \mu \mathrm{g} \mathrm{POC}{ }^{-1} \mathrm{~h}^{-1}$ at $100 \mathrm{nM}$ DFe to $29.4 \mathrm{ng} \mathrm{C} \mu \mathrm{g} \mathrm{POC}^{-1} \mathrm{~h}^{-1}$ at $5 \mathrm{nM} \mathrm{DFe}$, while $\mathrm{DPP}^{\mathrm{POC}}$ remained unchanged $(\mathrm{p} \geq 0.05$, Table 1$)$. $\mathrm{TPP}^{\mathrm{POC}}$ in the exponential phase were not significantly different between the $5 \mathrm{nM}$ and $13 \mathrm{nM}$ DFe treatments.

The mean PER during the exponential growth phase represented $10.6 \pm 4.8 \%, 8.6 \pm 4.3 \%$ and $2.5 \pm 1.1 \%$ of the TPP for the $5 \mathrm{nM} \mathrm{DFe}, 13 \mathrm{nM}$ DFe and $100 \mathrm{nM}$ DFe treatments, respectively (Fig. 2B, Table 1). PER was significantly lower $(p<0.05)$ in the highest Fe cultures during the exponential phase. There was no significant difference in PER in the $5 \mathrm{nM}$ DFe and $13 \mathrm{nM}$ DFe cultures during the exponential phase. After the exponential phase, PER continued to decrease until Day 11 and, thereafter, increased to maximum values at Day 13, ranging from about $10 \%$ for $100 \mathrm{nM}$ DFe to $23 \%$ for $13 \mathrm{nM}$ DFe.
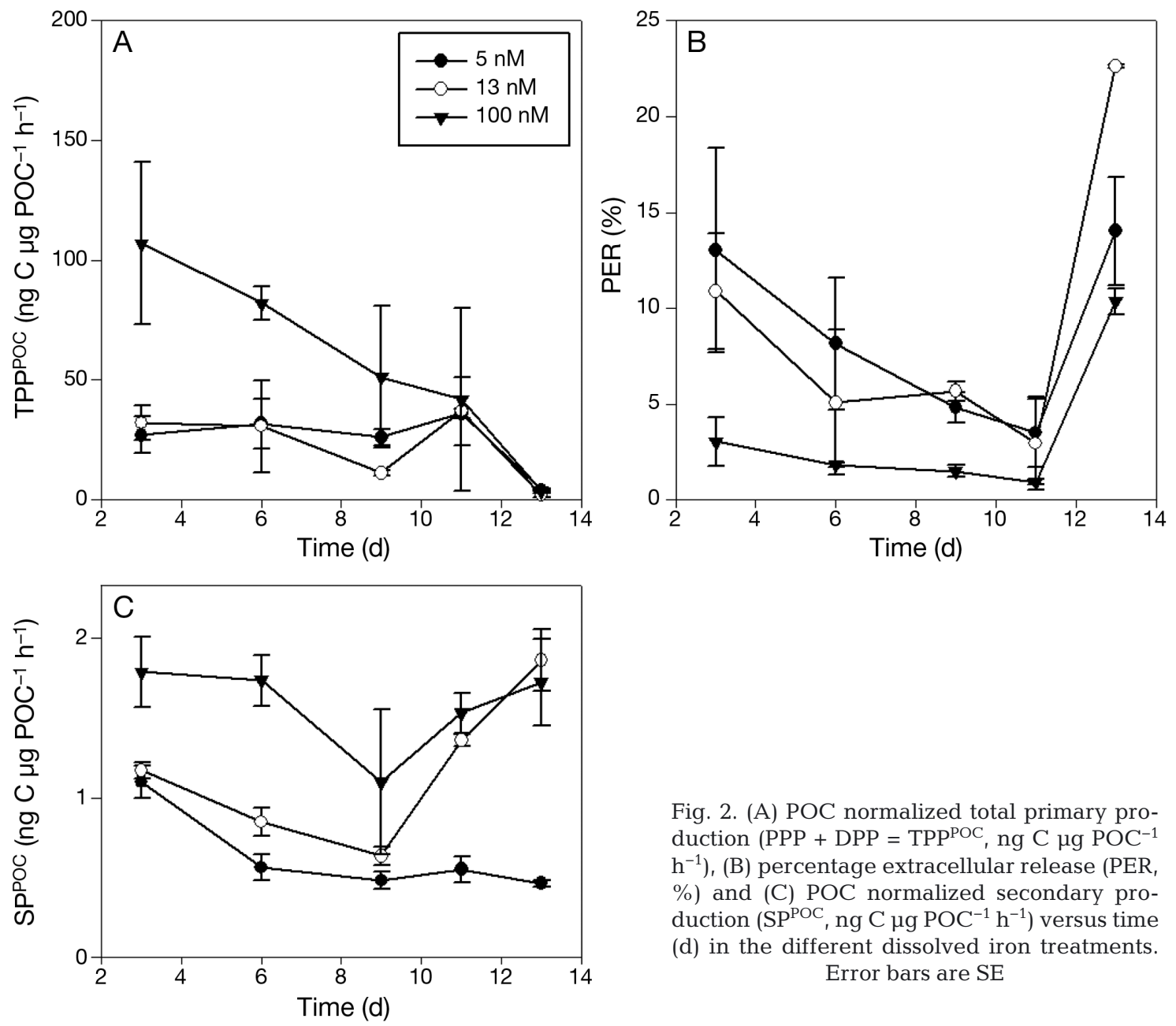

Fig. 2. (A) POC normalized total primary production $\left(\mathrm{PPP}+\mathrm{DPP}=\mathrm{TPP} \mathrm{POC}^{\mathrm{ng}} \mathrm{C} \mu \mathrm{g} \mathrm{POC}^{-1}\right.$ $\left.\mathrm{h}^{-1}\right)$, (B) percentage extracellular release (PER, $\%)$ and (C) POC normalized secondary production ( $\mathrm{SP}^{\mathrm{POC}}$, ng C $\mu \mathrm{g} \mathrm{POC}^{-1} \mathrm{~h}^{-1}$ ) versus time (d) in the different dissolved iron treatments. Error bars are SE 
The average rates of $\mathrm{SP}^{\mathrm{POC}}$ during the exponential phase ranged between $0.83 \pm 0.31 \mathrm{ng} \mathrm{C} \mu \mathrm{POC}^{-1} \mathrm{~h}^{-1}$ and $1.8 \pm 0.2 \mathrm{ng} \mathrm{C} \mu \mathrm{g} \mathrm{POC}{ }^{-1} \mathrm{~h}^{-1}$ for the $5 \mathrm{nM} \mathrm{DFe}$ and $100 \mathrm{nM} \mathrm{DFe}$, respectively, and were significantly different between treatments $(p<0.05$, Table 1$)$. SP ${ }^{\text {POC }}$ rates decreased between Day 3 and 9 in all treatments and, thereafter, increased to $1.86 \pm 0.19$ and $1.72 \pm 0.27 \mathrm{ng} \mathrm{C} \mu \mathrm{POC}^{-1} \mathrm{~h}^{-1}$ in the $13 \mathrm{nM} \mathrm{DFe}$ and $100 \mathrm{nM}$ DFe treatments, respectively. However, $\mathrm{SP}^{\mathrm{POC}}$ continued to decrease in the lowest $\mathrm{Fe}^{\prime}$ treatment to $0.46 \pm 0.02 \mathrm{ng} \mathrm{C} \mu \mathrm{POC}^{-1} \mathrm{~h}^{-1}$ by Day 13. Fe limitation led to a strong decrease in $\mathrm{SP}^{\mathrm{POC}}$ rates as shown by a 2.2-fold difference during the exponential phase between the highest and the lowest DFe concentration (Fig. 2C, Table 1).

The ratio of SP:TPP calculated for the exponential growth phase did not vary significantly with $\mathrm{DFe}^{\prime}$ concentration (Table 1). This is in contrast to SP:DPP, a measure of the potential amount of extracellular release (DPP) that is incorporated into microbial biomass (Table 1). The ratio of SP:DPP decreased by a factor of almost 3 from 0.85 to 0.30 from the highest to lowest DFe concentrations, indicating a strong effect of Fe limitation of SP:DPP.

We calculated a carbon budget for the partitioning of carbon fixed during primary production for Trichodesmium grown under Fe limitation (Table 2). TPP ${ }^{\mathrm{POC}}$ varied between 0.35 and $1.16 \mathrm{~d}^{-1}$ for the lowest and highest DFe concentrations, respectively, considering a $12 \mathrm{~h}$ light period and assuming that photosynthesis was constant over the light period. The percentage of this photosynthetically fixed carbon used for growth was $43 \%$ for the lowest DFe concentration, $61 \%$ for the intermediate DFe concentration and, interestingly, $29 \%$ for the highest DFe

Table 2. Estimated carbon budget for Trichodesmium grown under 3 DFe concentrations. TPP ${ }^{\mathrm{POC}}$ (ng C $[\text { ng POC }]^{-1} \mathrm{~h}^{-1}$ ) was simplified mathematically to TPP ${ }^{\mathrm{POC}}\left(\mathrm{h}^{-1}\right)$. The daily TPP POC $\left(d^{-1}\right)$ was then calculated for a day length of $12 \mathrm{~h}$. The percentage of carbon used for algal growth was calculated using daily growth rate $(\mu)$ and daily $\mathrm{TPP}^{\mathrm{POC}}$ where $\% \mathrm{TPP}^{\mathrm{POC}}$ used for algal growth $=\mu / \mathrm{TPP}^{\mathrm{POC}} \times 100$. The percentage of carbon respired was calculated as $\mathrm{C}_{\text {respired }}=100-$ (\% TPP ${ }^{\mathrm{POC}}$ used for growth + PER)

\begin{tabular}{|lccc|}
\hline \multirow{2}{*}{ Variable } & \multicolumn{4}{c|}{ DFe roncentration (nM) } \\
& 5 & 13 & 100 \\
\hline $\mathrm{TPP}^{\mathrm{POC}}\left(\mathrm{d}^{-1}\right)$ & 0.35 & 0.38 & 1.16 \\
Percentage of TPP & & & \\
$\quad$ used for algal growth $(\%)$ & 42.9 & 60.5 & 29.3 \\
PER $(\%)$ & 10.6 & 8.6 & 2.5 \\
$\mathrm{C}_{\text {respired }}(\%)$ & 46.5 & 30.9 & 68.2 \\
\hline
\end{tabular}

concentration. Considering the percentage of carbon fixed during photosynthesis and lost as extracellular release (PER), we then calculated that at the lowest DFe concentrations up to $46.5 \%$ of the carbon fixed during photosynthesis could be lost as respiration. This decreased to $31 \%$ for the intermediate DFe concentration and then increased by a factor of $\sim 2$ to almost $70 \%$ for the highest DFe concentration.

\section{DISCUSSION}

Here, we examined the impact of Fe limitation on TPP, PER and SP in Trichodesmium, a diazotrophic cyanobacterium, during a series of culture incubations. Reduced Fe concentrations induced a decrease in final cell biomass, specific growth rate, $\mathrm{N}_{2}$-fixation rates and $\mathrm{TPP}^{\mathrm{POC}}$ of Trichodesmium, and an increase in the cellular $\mathrm{C}: \mathrm{N}$ ratio in the exponential phase. The lowest DFe concentration led to 2.3-, 5-, 2.8- and 3.3-fold decreases in specific growth rate, $\mathrm{N}_{2}$-fixation rate and $\mathrm{TPP}^{\mathrm{POC}}$ in the exponential phase as compared to the highest DFe concentration. In Bucciarelli et al. (2013), the growth rate of Trichodesmium under Fe replete condition $(\mathrm{DFe}=400 \mathrm{nM})$ was $0.46 \mathrm{~d}^{-1}$, which suggests that the lower growth rates of Trichodesmium in the $100 \mathrm{nM}$ DFe culture $\left(\mu=0.34 \mathrm{~d}^{-1}\right)$ may have been caused by the 4 -fold lower Fe concentration. The 1.5-fold increase in $\mathrm{C}: \mathrm{N}$ ratio (from 5.4 to 8.0) when Fe stress increased is in good agreement with the findings of Bucciarelli et al. (2013) who have shown that the C:N ratio of Trichodesmium varied from 5.1 under $\mathrm{Fe}$ replete conditions $(\mathrm{DFe}=$ $400 \mathrm{nM}$ ) to 8.1 under Fe limitation (DFe $=8 \mathrm{nM})$. The increased cellular C: $\mathrm{N}$ ratio indicates that $\mathrm{N}_{2}$ fixation is more affected by Fe limitation than $\mathrm{CO}_{2}$ fixation ( $\mathrm{TPP}^{\mathrm{POC}}$ ) as shown by the 5 -fold decrease in $\mathrm{N}_{2}$ fixation and the lower 3.3-fold decrease in TPP. Moreover, while it has been shown in previous studies that Fe limitation reduces $\mathrm{CO}_{2}$ fixation by Trichodesmium (Paerl et al. 1994), we show for the first time that Fe limitation leads to a significant increase in PER and that Fe limitation decreases the microbial utilization rate of that extracellular release (SP) and induces a drop in SP:DPP.

\section{Impact of Fe limitation on the carbon budget of Trichodesmium}

Fe limitation also influenced the partitioning of photosynthetically fixed organic carbon between cellular growth and respiration. At the highest Fe con- 
centration, only $\sim 30 \%$ of the photosynthetically fixed $\mathrm{C}$ was incorporated into cellular biomass and a small portion $(2 \%)$ was excreted; the main part of the photosynthetic fixed C was utilized for respiration (68\%, Table 2), thus providing a source of energy as ATP for the high energy requirements of $\mathrm{N}_{2}$ fixation. At the intermediate Fe concentration (13 nM DFe), a higher proportion of photosynthetically fixed $\mathrm{C}$ was incorporated into cellular biomass $(61 \%)$, meaning that a lower proportion was used to support cellular respiration (31\%). This decrease in the cellular respiration is consistent with the 2.8-fold decrease in the $\mathrm{C}$-normalized rate of $\mathrm{N}_{2}$ fixation (Table 1) relative to the $100 \mathrm{nM}$ DFe treatment. At the lowest Fe concentration ( $5 \mathrm{nM} \mathrm{DFe}$ ), $43 \%$ of photosynthetic $\mathrm{C}$ is incorporated into algal biomass with an estimated $47 \%$ being lost as respiration. Given the lower $\mathrm{N}_{2}$-fixation and primary production rates at the lowest Fe concentration, it is probable that the higher percentage of fixed C used for respiration may reflect an increasing importance of basal respiration to the overall cellular carbon budget at very low specific growth rates. Therefore, Fe limitation not only limits $\mathrm{N}_{2}$ and $\mathrm{CO}_{2}$ fixation but it also plays an important role in determining the partitioning of fixed $\mathrm{C}$ between algal biomass, extracellular release and the proportion used for cellular respiration.

\section{Impact of Fe limitation on dissolved primary production}

Fe is an essential element in nitrate and nitrite reductase, enzymes necessary for the utilization of nitrate/nitrite by phytoplankton (Berges \& Harrison 1995). In diazotrophic cyanobacteria, as Fe is at the core of the nitrogenase enzymes needed to fix $\mathrm{N}_{2}$, the Fe requirements are even higher during $\mathrm{N}_{2}$ fixation when Fe requirements are up to 5-fold higher than during $\mathrm{NH}_{4}{ }^{+}$utilization (Kustka et al. 2003b). Interestingly, PER increased under strong Fe limitation $(\sim 11 \%$ at $\mathrm{DFe}=5 \mathrm{nM})$ as well as the percentage of photosynthetically fixed carbon incorporated into cellular biomass (Table 2). PER found in the highest Fe treatment (exponential phase: $2.2 \pm 1.1 \%$ ) was of the same order of magnitude than those previously published during a bloom of Trichodesmium spp. in the lagoon of New Caledonia by Renaud et al. (2005) (close to $1 \%$, Renaud et al. 2005). Berman-Frank et al. (2007b) looking at programmed cell death (PCD) in Trichodesmium sp. also reported that under severe Fe stress the release of organic matter increased. However, these authors measured transparent exo- polymer particle (TEP) production which forms part of the particulate organic phase and not the dissolved phase as measured here. Moreover, Berman-Frank et al. (2007b) found that TEP production did not occur under active growth and so it is probable that another mechanism other than PCD occurred in the work presented here, at least during the active growth phase.

The production and release of DOC during photosynthesis is influenced by many factors such as nutrient limitation, light and temperature shifts and the presence of contaminants (e.g. Obernosterer \& Herndl 1995, Conan et al. 2008, Rochelle-Newall et al. 2008a, Halewood et al. 2012). Our cultures were incubated at light levels and at temperatures to which the cultures were acclimated for at least 10 generations and which are considered optimal for the Trichodesmium spp. growth. Furthermore, we kept the manipulations of the cultures to a minimum and reduced sampling time to a minimum. It is, therefore, probable that light and temperature shifts do not explain the increased PER. Moreover, all cultures were treated in the same way during sample collection.

The measurement of DPP and PER is fraught with methodological difficulties (Karl et al. 1998, Morán \& Estrada 2001, Marañón et al. 2004, Kiene \& Slezak 2006). Indeed, to reduce the potential methodological problems, we used gentle vacuum filtration and filtered the smallest volumes possible in order to have a good ratio between samples and blanks for the ${ }^{14} \mathrm{C}$ measurements. We also tried to keep incubation time as short as possible in order to minimize the recycling of DPP (Glibert \& Bronk 1994) and used $0.4 \mu \mathrm{m}$ polycarbonate filters over the GF/F filters as previous work has shown that ${ }^{14} \mathrm{C}$-DOC tends stick to GF/F filters (Morán et al. 1999). Consequently, the increase in PER observed in the strongly Fe-limited cultures is probably due to cellular stress induced by Fe limitation.

It has been proposed that extracellular release represents a way of 'dumping' excess photosynthates when insufficient nutrients are available for the production of cellular material (Fogg 1966, Lancelot 1983, Obernosterer \& Herndl 1995). Fe stress induces nitrogen limitation in Trichodesmium, thus limiting the available reduced nitrogen for the production of cellular material. It can also be argued that Fe stress also directly limits rates of photosynthetic $\mathrm{C}$ fixation, which may also reduce the supply of available fixed carbon for excretion as DPP, although this does not seem to be the case in our work as PER increased with increasing Fe limitation. The lack of inorganic $\mathrm{N}$ source in our culture media and the reduced rates of 
$\mathrm{N}_{2}$ fixation in the $\mathrm{Fe}$ depleted cultures meant that there may have been some nitrogen limitation of heterotrophic processes.

It has also been proposed that extracellular release is an active process with the goal of 'collecting' or 'mopping up' micronutrients such as essential metals (Zhou \& Wangersky 1989, González-Dávila 1995, Croot et al. 2000). DPP and DOC, in general, are known to have high chelating properties for metals (Wells 1998, 2002). Therefore, under Fe limitation, extracellular release may well provide a strategy for diazotrophic cyanobacteria to increase their $\mathrm{Fe}$ uptake capacities. To date, Trichodesmium has not been shown to produce siderophores (strong Febinding ligands) under Fe-limiting conditions. Moreover, $\mathrm{Fe}$ bound to strong siderophore complexes is not easily accessible to Trichodesmium IMS101 in Fe-limited cultures, although $\mathrm{Fe}$ in association with weak organic ligands is more readily bioavailable (Roe et al. 2012). Saccharides may act like weak organic ligands and these $\mathrm{Fe}$ complexes may be taken up directly via the reductive iron uptake pathway (Hassler et al. 2011, Shaked \& Lis 2012).

\section{Transfer of carbon}

We observed a decrease in both $\mathrm{SP}^{\mathrm{POC}}$ and SP:DPP with decreasing Fe concentration and this was despite significantly higher PER rates in the lowest Fe concentration. This decrease in $\mathrm{SP}^{\mathrm{POC}}$ and in SP:DPP under severe $\mathrm{Fe}$ limitation suggests that $\mathrm{Fe}$, either directly through influencing heterotrophic cellular processes or indirectly through influencing organic matter structure or nitrogen availability, is controlling heterotrophic secondary production and, thus, microbial utilization of DOC.

Microbial utilization of DOC is strongly related to bacterial growth efficiency (e.g. Sinsabaugh \& Findlay 2003, Rochelle-Newall et al. 2004) and both are dependent upon several factors, notably macro- and micro-nutrient availability and upon DOC chemical structure (Bertilsson \& Jones 2003). Kroer (1993) found that bacterial activity and growth efficiency was reduced under low nitrogen concentration and under high dissolved $\mathrm{C}: \mathrm{N}$ ratios in a series of culture incubations. Given the low $\mathrm{N}_{2}$-fixation rates in the lowest Fe concentration, heterotrophic production may have been limited by high dissolved C: $\mathrm{N}$ ratios. Thus, Fe may have, through its influence of $\mathrm{N}_{2}$ and $\mathrm{CO}_{2}$ fixation, indirectly influenced SP and SP:DPP.

The chemical structure of dissolved organic matter also plays a role in determining its utilization by het- erotrophs (Sinsabaugh \& Findlay 2003). The chemical characteristics of organic matter released during photosynthesis change as a function of growth stage and as a function of nutrient limitation (Biersmith \& Benner 1998, Kragh \& Sondergaard 2009). Although it is difficult to accurately evaluate this factor without in-depth chemical analyses of the DOC released during photosynthesis, it has been previously shown that the bioavailability of DPP from a natural population of Trichodesmium spp. to heterotrophic bacteria was low during active growth and that the bioavailability increased rapidly towards the end of the bloom (Renaud et al. 2005). It is, therefore, possible that Fe limitation not only led to increased DPP production but also to a shift in the chemical characteristics of that DPP in the different Fe treatments, thus indirectly affecting SP and the uptake of DPP.

Fe plays an important role in cellular function and limiting concentrations of this essential element can directly influence heterotrophic processes. Recent work highlighted widespread presence of Fe uptake mechanisms in heterotrophic marine bacteria (e.g. Nies 1999, Toulza et al. 2012). Tortell et al. (1996) proposed that marine heterotrophic bacteria account for between 20 and $45 \%$ of biological carbon uptake in the ocean and that, at limiting $\mathrm{Fe}^{\prime}$ concentrations $\left(0.025 \mathrm{nM} \mathrm{Fe}^{\prime}\right)$, bacterial carbon growth efficiency is reduced. Even though their limiting concentration is about one order of magnitude lower than our lowest $\mathrm{Fe}^{\prime}$ concentration $(0.26 \mathrm{nM} \mathrm{Fe}$ corresponding to $\mathrm{DFe}=5 \mathrm{nM}$, Table 1) at which we observed the lowest SP rates and the lowest SP:DPP values, the low Fe concentration in our cultures could have directly limited the metabolism and growth of the bacteria. However, it is difficult to compare the values of SP:DPP with other values, as other published data tend to come from in situ work where external organic matter supplies and contaminants play an important role in determining SP:TPP or SP:DPP (e.g. RochelleNewall et al. 2008b, Fouilland \& Mostajir 2010, Rochelle-Newall et al. 2011). Nevertheless, our results mean that the amount of carbon entering into the microbial loop is reduced under Fe limitation, thus leading to an accumulation of DOC with potentially important impacts on microbial carbon cycling and, ultimately, on the biological carbon pump.

In this work, we used a fixed empirical conversion factor (1.55 kg C mol${ }^{-1}$ of leucine incorporated) to obtain SP. However, given the potential nitrogen limitation in the Fe-limited cultures, it is probable that the conversion factor used overestimated SP. Indeed, it has been proposed that nutrient limitation leads to a decrease in the amount of carbon biomass pro- 
duced per mole of leucine incorporated into the cell in situ (Calvo-Díaz \& Morán 2009). Whether or not this also occurs in cyanobacterial cultures under Fe limitation has yet to be determined. Nevertheless, if we assume that the same mechanism occurs in Felimited cultures as in situ, it is probable that our SP rates were overestimated in the cultures under nutrient limitation (i.e. in the lowest Fe concentrations). This caveat should be kept in mind when considering our calculations of the transfer of carbon from autotrophic production to heterotrophic uptake (SP:TPP and SP:DPP, Table 1).

\section{CONCLUSIONS}

Future scenarios of global change suggest climate change will alter the biogeochemical cycling of Fe, but how remains an open question (Boyd \& Ellwood 2010). Moreover, the impacts of Fe limitation on the production and transfer of organic carbon from Trichodesmium and other diazotrophic cyanobacteria to the microbial loop need to be further investigated, particularly in in situ conditions that take into account the diversity of the associated bacterial heterotrophs. Our results show that under severe Fe limitation, the relative rates of $\mathrm{PER}$ increased and that the rate of microbial utilization of DOC was reduced. This would in turn lead to a potential malfunctioning of the microbial loop (e.g. Thingstad et al. 1997) under Fe limitation and to the accumulation of DOC in the water column. Undoubtedly, future studies that look at the impact of Fe limitation of TPP and $\mathrm{N}_{2}$ fixation need to take into account the impact of Fe limitation on DPP and PER and on the impact of this limitation on the microbial utilization of that organic matter and associated growth of bacterial communities.

Acknowledgements. The work was financed by the French ANR Blanc 'Boa' (Biogéochimie du fer à l'interface OcéanAtmosphère: interactions entre apports atmosphériques de fer et réseau trophique, JC05_45426) and the French Institut de Recherche pour le Développement (IRD). Adriana Crete is greatly thanked for her help with the Trichodesmium biomass determinations. We also thank Dr. B. Sunda and an anonymous reviewer who greatly helped to improve the article.

\section{LITERATURE CITED}

Berges JA, Harrison PJ (1995) Nitrate reductase activity quantitatively predicts the rate of nitrate incorporation under steady state light limitation: a revised assay and characterization of the enzyme in 3 species of marine phytoplankton. Limnol Oceanogr 40:82-93
Berman-Frank I, Cullen JT, Shaked Y, Sherrell RM, Falkowski PG (2001) Iron availability, cellular iron quotas, and nitrogen fixation in Trichodesmium. Limnol Oceanogr 46:1249-1260

> Berman-Frank I, Quigg A, Finkel ZV, Irwin AJ, Haramaty L (2007a) Nitrogen-fixation strategies and Fe requirements in cyanobacteria. Limnol Oceanogr 52:2260-2269

Berman-Frank I, Rosenberg G, Levitan O, Haramaty L, Mari X (2007b) Coupling between autocatalytic cell death and transparent exopolymeric particle production in the marine cyanobacterium Trichodesmium. Environ Microbiol 9:1415-1422

Bertilsson S, Jones JB (2003) Supply of dissolved organic matter to aquatic ecosystems: autochthonous sources. In: Findlay S, Sinsabaugh R (eds) Aquatic ecosystems: interactivity of dissolved organic matter. Academic Press, San Diego, CA, p 3-24

> Biersmith A, Benner R (1998) Carbohydrates in phytoplankton and freshly produced dissolved organic matter. Mar Chem 63:131-144

Boyd PW, Ellwood MJ (2010) The biogeochemical cycle of iron in the ocean. Nat Geosci 3:675-682

> Bucciarelli E, Ridame C, Sunda WG, Dimier-Hugueney C, Cheize M, Belviso S (2013) Increased intracellular concentration of DMSP and DMSO in iron-limited oceanic phytoplankton Thalassiosira oceanica and Trichodesmium erythraeum. Limnol Oceanogr 58:1667-1679

> Calvo-Díaz A, Morán XAG (2009) Empirical leucine-tocarbon conversion factors for estimating heterotrophic bacterial production: seasonality and predictability in a temperate coastal ecosystem. Appl Environ Microbiol 75: 3216-3221

> Capone DG (2001) Marine nitrogen fixation: What's the fuss? Curr Opin Microbiol 4:341-348

Carlson CA (2002) Production and removal processes. In: Hansell DA, Carlson CA (eds) Marine dissolved organic matter. Academic Press, San Diego, CA, p 91-152

> Chen YB, Zehr JP, Mellon M (1996) Growth and nitrogen fixation of the diazotrophic filamentous nonheterocystous cyanobacterium Trichodesmium sp. IMS 101 in defined media: evidence for a circadian rhythm. J Phycol 32:916-923

> Conan P, Joux F, Torréton JP, Pujo-Pay M, Douki T, Rochelle-Newall E, Mari X (2008) Effect of solar ultraviolet radiation on bacterio- and phytoplankton activity in a large coral reef lagoon (southwest New Caledonia). Aquat Microb Ecol 52:83-98

$>$ Croot PL, Moffett JW, Brand LE (2000) Production of extracellular $\mathrm{Cu}$ complexing ligands by eucaryotic phytoplankton in response to $\mathrm{Cu}$ stress. Limnol Oceanogr 45: 619-627

Fogg GE (1966) The extracellular products of algae. Oceanogr Mar Biol Annu Rev 4:195-212

Fouilland E, Mostajir B (2010) Revisited phytoplanktonic carbon dependency of heterotrophic bacteria in freshwaters, transitional, coastal and oceanic waters. FEMS Microbiol Ecol 73:419-429

Glibert PM, Bronk DA (1994) Release of dissolved organic nitrogen by marine diazotrophic cyanobacteria, Trichodesmium spp. Appl Environ Microbiol 60:3996-4000

> González-Dávila M (1995) The role of phytoplankton cells on the control of heavy metal concentration in seawater. Mar Chem 48:215-236

> Halewood ER, Carlson CA, Brzezinski MA, Reed DC, Goodman J (2012) Annual cycle of organic matter parti- 
tioning and its availability to bacteria across the Santa Barbara Channel continental shelf. Aquat Microb Ecol 67:189-209

Hassler CS, Schoemann V, Nichols CM, Butler ECV, Boyd PW (2011) Saccharides enhance iron bioavailability to Southern Ocean phytoplankton. Proc Natl Acad Sci USA 108:1076-1081

- Hudson RJM, Covault DT, Morel FMM (1992) Investigations of iron coordination and redox reactions in seawater using ${ }^{59} \mathrm{Fe}$ radiometry and ion-pair solvent extraction of amphiphilic iron complexes. Mar Chem 38:209-235

> Jacq V, Ridame C, L'Helguen S, Kaczmar F, Saliot (2014) Response of the unicellular diazotrophic cyanobacterium Crocosphaera watsonii to iron limitation. PLoS ONE: e86749

Kamjunke N, Tittel J (2008) Utilisation of leucine by several phytoplankton species. Limnologica 38:360-366

Karl DM, Hebel DV, Bjökman K, Letelier RM (1998) The role of dissolved organic matter release in the productivity of the oligotrophic North Pacific Ocean. Limnol Oceanogr 43:1270-1286

Kiene RP, Slezak D (2006) Low dissolved DMSP concentrations in seawater revealed by small-volume gravity filtration and dialysis sampling. Limnol Oceanogr Methods 4: 80-95

Kirchman D (2001) Measuring bacterial biomass production and growth rates from leucine incorporation in natural aquatic environments. In: John HP (ed) Methods in microbiology, Vol 30. Academic Press, St. Petersburg, FL, p 227-237

Kragh T, Sondergaard M (2009) Production and decomposition of new DOC by marine plankton communities: carbohydrates, refractory components and nutrient limitation. Biogeochemistry 96:177-187

Kroer N (1993) Bacterial growth efficiency on natural dissolved organic matter. Limnol Oceanogr 38:1282-1290

Küpper H, Šetlík I, Seibert S, Prášil O and others (2008) Iron limitation in the marine cyanobacterium Trichodesmium reveals new insights into regulation of photosynthesis and nitrogen fixation. New Phytol 179:784-798

- Kustka A, Sanudo-Wilhelmy S, Carpenter EJ, Capone DG, Raven JA (2003a) A revised estimate of the iron use efficiency of nitrogen fixation, with special reference to the marine cyanobacterium Trichodesmium spp. (Cyanophyta). J Phycol 39:12-25

> Kustka AB, Sanudo-Wilhelmy SA, Carpenter EJ, Capone D, Burns J, Sunda WG (2003b) Iron requirements for dinitrogen- and ammonium-supported growth in cultures of Trichodesmium (IMS 101): comparison with nitrogen fixation rates and iron: carbon ratios of field populations. Limnol Oceanogr 48:1869-1884

Lancelot C (1983) Factors affecting phytoplankton extracellular release in the Southern Bight of the North Sea. Mar Ecol Prog Ser 12:115-121

Marañón E, Cermeño P, Fernández E, Rodríguez J, Zabala L (2004) Significance and mechanisms of photosynthetic production of dissolved organic carbon in a coastal eutrophic ecosystem. Limnol Oceanogr 49:1652-1666

Michaels AF, Karl DM, Capone DG (2001) Element stoichiometry, new production and nitrogen fixation. Oceanography 14:68-77

Mills MM, Ridame C, Davey M, La Roche J, Geider RJ (2004) Iron and phosphorus co-limit nitrogen fixation in the eastern tropical North Atlantic. Nature 429:292-294 Montoya JP, Voss M, Kahler P, Capone DG (1996) A simple, high-precision, high-sensitivity tracer assay for N(inf2) fixation. Appl Environ Microbiol 62:986-993

> Moore CM, Mills MM, Achterberg EP, Geider RJ and others (2009) Large-scale distribution of Atlantic nitrogen fixation controlled by iron availability. Nat Geosci 2:867-871

Morán XAG, Estrada M (2001) Short-term variability of photosynthetic parameters and particulate and dissolved primary production in the Alboran Sea (SW Mediterranean). Mar Ecol Prog Ser 212:53-67

> Morán XAG, Gasol JM, Arin L, Estrada M (1999) A comparison between glass fiber and membrane filters for the estimation of phytoplanktonic POC and DOC production. Mar Ecol Prog Ser 187:31-41

> Mulholland MR, Rocha AM, Boneillo GE (2011) Incorporation of leucine and thymidine by estuarine phytoplankton: implications for bacterial productivity estimates. Estuaries Coasts 34:310-325

Nagata T (2000) Production mechanisms of dissolved organic matter. In: Kirchman DL (ed) Microbial ecology of the oceans. John Wiley \& Sons, New York, NY, p 121-152

Nausch M (1996) Microbial activities on Trichodesmium colonies. Mar Ecol Prog Ser 141:173-181

Nies DH (1999) Microbial heavy-metal resistance. Appl Microbiol Biotechnol 51:730-750

> Norrman B, Zweifel UL, Hopkinson CS, Fry B (1995) Production and utilization of dissolved organic carbon during an experimental diatom bloom. Limnol Oceanogr 40: 898-907

Obernosterer I, Herndl GJ (1995) Phytoplankton extracellular release and bacterial growth: dependence on the inorganic N:P ratio. Mar Ecol Prog Ser 116:247-257

Paerl HW, Prufertbebout LE, Guo CZ (1994) Iron-stimulated $\mathrm{N}_{2}$ fixation and growth in natural and cultural population of the planktonic marine cyanobacteria Trichodesmium spp. Appl Environ Microbiol 60:1044-1047

> Renaud F, Pringault O, Rochelle-Newall E (2005) Effects of the colonial cyanobacterium Trichodesmium spp. on bacterial activity. Aquat Microb Ecol 41:261-270

Ridame C, Le Moal M, Guieu C, Ternon E, Biegala IC, L'Helguen S, Pujo-Pay M (2011) Nutrient control of $\mathrm{N}_{2}$ fixation in the oligotrophic Mediterranean Sea and the impact of Saharan dust events. Biogeosciences 8: 2773-2783

Rochelle-Newall EJ, Pizay MD, Middelburg JJ, Boschker HTS, Gattuso JP (2004) Degradation of riverine dissolved organic matter by seawater bacteria. Aquat Microb Ecol $37: 9-22$

> Rochelle-Newall EJ, Delesalle B, Mari X, Rouchon C, Torréton JP, Pringault O (2008a) Zinc induces shifts in microbial carbon flux in tropical coastal environments. Aquat Microb Ecol 52:57-68

Rochelle-Newall EJ, Torréton JP, Mari X, Pringault O (2008b) Phytoplankton-bacterioplankton coupling in a subtropical South Pacific coral reef lagoon. Aquat Microb Ecol 50:221-229

> Rochelle-Newall EJ, Chu VT, Pringault O, Amouroux D and others (2011) Phytoplankton diversity and productivity in a highly turbid, tropical coastal system (Bach Dang Estuary, Vietnam). Mar Pollut Bull 62:2317-2329

> Roe KL, Barbeau K, Mann EL, Haygood MG (2012) Acquisition of iron by Trichodesmium and associated bacteria in culture. Environ Microbiol 14:1681-1695

Rubin M, Berman-Frank I, Shaked Y (2011) Dust- and mineral-iron utilization by the marine dinitrogen-fixer Trichodesmium. Nat Geosci 4:529-534 
Shaked Y, Lis H (2012) Disassembling iron availability to phytoplankton. Frontiers Microbiol 3:1-26

Sinsabaugh RL, Findlay SEG (2003) Dissolved organic matter: out of the black box and into the mainstream. In: Findlay SEG, Sinsabaugh RL (eds) Aquatic ecosystems: interactivity of dissolved organic matter. Academic Press, San Diego, CA, p 479-498

Smith DC, Azam F (1992) A simple, economical method for measuring bacterial protein synthesis rates in seawater using ${ }^{3} \mathrm{H}$-leucine. Mar Microb Food Webs 6:107-114

Sunda WG, Huntsman S (2003) Effect of pH, light, and temperature on Fe-EDTA chelation and Fe hydrolysis in seawater. Mar Chem 84:35-47

Thingstad TF, Hagstrom A, Rassoulzadegan F (1997) Accumulation of degradable DOC in surface waters: Is it caused by a malfunctioning microbial loop? Limnol Oceanogr 42:398-404

Editorial responsibility: Patricia Glibert, Cambridge, Maryland, USA
Tortell PD, Maldonado MT, Price NM (1996) The role of heterotrophic bacteria in iron-limited ocean ecosystems. Nature 383:330-332

Toulza E, Tagliabue A, Blain S, Piganeau G (2012) Analysis of the global ocean sampling (GOS) project for trends in iron uptake by surface ocean microbes. PLoS ONE 7: e30931

Wells ML (1998) Marine colloids: a neglected dimension. Nature 391:530-531

Wells ML (2002) Marine colloids and trace metals. In: Hansell D, Carlson CA (eds) Biogeochemistry of marine dissolved organic matter. Elsevier, New York, NY, p 367-404

Zhou X, Wangersky PJ (1989) Production of copper-complexing organic ligands by the marine diatom Phaeodactylum tricornutum in a cage culture turbidostat. Mar Chem 26:239-259

Submitted: March 18, 2013; Accepted: February 14, 2014 Proofs received from author(s): April 16, 2014 